\title{
Cracked tooth syndrome
}

\author{
Maria Tanumihardja \\ Department of Conservative \\ Faculty of Dentistry, Hasanuddin University \\ Makassar, Indonesia
}

\begin{abstract}
ABSTRAK
Cracked tooth syndrome sering ditemukan dalam praktek sehari-hari. Tingkat kejadian gigi yang mengalami retakan cenderung meningkat. Hal ini terjadi karena usia manusia yang bertambah panjang dan gigi dapat bertahan lebih lama. Sebagai akibatnya, manusia memiliki gigi dengan perawatan saluran akar dan restorasi yang lebih kompleks, sehingga gigi lebih rentan terhadap retakan. Disamping itu, hidup yang penuh tekanan dapat memicu kebiasaan tanpa sadar seperti clenching dan bruksisma yang dapat merangsang retakan gigi. Akan tetapi, banyak gigi retak yang dapat diselamatkan bila tanda dan gejala khas dari sindroma retakan gigi dapat diketahui lebih awal.
\end{abstract}

Kata kunci: cracked tooth syndrome, diagnosis, penanganan

\begin{abstract}
Cracked tooth syndrome is usually found in daily dental practice. The incidence of cracks teeth tends to increasing. People are living longer and keeping their teeth longer. As a consequence, people have more complex restoration and endodontic treatment, leaving teeth more prone to cracks. In addition, stressful lives may provoke unconscious habits such as clenching and bruxism which can induce cracks in teeth. However, many cracks teeth can be saved nowadays when the characteristic signs and symptoms of cracked tooth syndrome can be diagnosed earlier in its development.
\end{abstract}

Key word: cracked tooth syndrome, diagnose, management

Correspondence: Maria Tanumihardja, Department of Conservative, Faculty of Dentistry Hasanuddin University, Jl. Perintis Kemerdekaan Km.10, Tamalanrea, Makassar, Indonesia. E-mail: mariatan@telkom.net.id.

\section{INTRODUCTION}

Cracked tooth syndrome is defined as an incomplete fracture of the dentine in a vital posterior tooth that may involve the dental pulp. ${ }^{1}$

Cameron in 1964 (cited from Ehrmann \& Tyas, and Mittal et al) was the first to describe the term 'cracked tooth syndrome' although the similar condition has been mentioned earlier by Gibbs which used the term 'cuspal fracture odontalgia.' Other terms such as 'hairline fracture', incomplete crown root fracture, split root syndrome, enamel infraction, crown craze, craze lines, and tooth structure cracks have been reported. $^{1,2}$

The symptoms will depend on the location and depth of the cracks, and the time between commencement of symptoms and diagnosis.

The most common cause of cracked tooth syndrome are masticatory or accidental trauma, unintentional biting with physiologic masticatory force or a small and very hard object may suddenly generate an excessive load that may 
cause the tooth to split. Other factors like extensive tooth preparation, increased deep carious lesions, deep groves or endodontic treated teeth may also make teeth susceptible to fracture. ${ }^{1-}$ 4

Also, morphologic, physical, and iatrogenic factors may predispose posterior teeth to cracks. According to Snyder, majority of the cases did not involve the pulp and ended above the epithelial attachment, in this case, patients feel little pain.

The aim of this article was to provide the description of cracked tooth syndrome and its management.

\section{LITERATURE REVIEW}

\section{Signs and symptoms}

Cracked tooth syndrome is not easily identified, until a variety of symptoms are present. Teeth tend to have erratic pain on mastication especially with release of biting pressure.

Sometimes, there is pain to temperature extremes, especially cold. However, the signs and symptoms may depend on the location, direction and extent of the crack. If the pulp is involved, there may be signs and symptoms of irreversible pulpitis or necrosis with periradicular pathosis. If the crack extends to the root surface, there may be a periodontal pocket. However, cracks can be finally identified when a variety of symptoms exist, a restoration is removed or significant periodontal defect is identified. ${ }^{1,2,4,5}$

A patient with a tooth crack can end up in the endodontist's office due to long history of uncertain diagnoses. Cracks in teeth usually progress slowly and when it is caught earlier and treated appropriately, the cracks can be stopped, thus preventing tooth loss.

\section{Incidence}

Most crack tooth syndrome occurs in unrestored tooth or completely free of caries/little or only class I restorations. According to Hyatt, $25 \%$ of cases occurred in teeth without restorations and $39 \%$ occurred in teeth with class I restorations. Only 26\% was class II restorations. Lower molars are commonly affected teeth with $40 \%$ of cases occurred in lower second molar, while 29\% occurred in lower first molars. Dewberry (cited from Ehrmann and Tyas, and Turp and Gobetti) reported higher percentage of cracked tooth syndrome occurred in lower first molar, (32\%) than lower second molar (30\%). Other teeth that may be affected by cracked tooth syndrome are upper first molar, upper second molar and upper premolar. Cracked tooth syndrome most commonly experienced by patients before 40 years of age and the youngest patients ever reported case was aged 26 years. Lack of knowledge among the clinicians have made cracked tooth syndrome frequently remained undiagnosed for many months. ${ }^{1,4}$

Snyder and Stidger (cited from Ehrmann and Tyas) reported 80 to 100 cases of cracked tooth syndrome per year in general practices. Cracks generally occur in a mesiodistal direction (81.1\%) and prevalent age was under 50 years, both men and women have similar percentage $(53.3 \%$ and $46.1 \%$ respectively).

\section{Diagnosis}

When a crack is suspected, steps should be taken immediately to confirm the presence of a crack, determine the type of crack and formulate an appropriate treatment plan. It is essential to reproduce the patient's symptoms in one of a number of ways. 

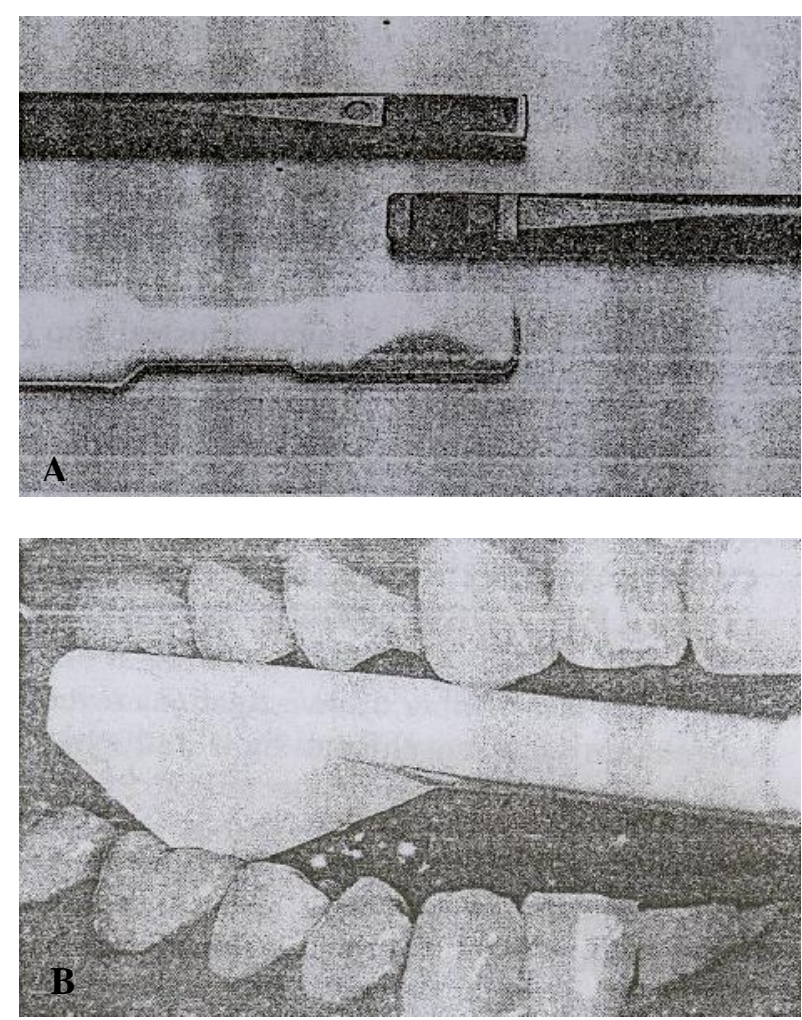

Figure 1. A. Tooth slot is used to apply biting pressure to cusps and fossae; B. The patient is asked to bite on each cusp, until the pain is reproduced (Source: Cohen S, Liewehr F. Diagnostic procedures in pathways of the pulp. $8^{\text {th }}$ Ed. St.Louis: Mosby Inc;2002. p.24-6).

Ehrmann and Tyas prefer to use an orange wood stick, rested on suspected tooth in each cusp and the patient is asked to bite. This may accurately localize the involved cusp. ${ }^{1}$

Kruger (cited from Ehrmann and Tyas) suggested to place a cotton wool roll on the suspected tooth, asked the patient to bite and to release the pressure suddenly. Pain felt upon the pressure release, confirms the diagnosis of cracked tooth syndrome. Other aid to the diagnosis of cracked tooth syndrome is tooth sloth which consists of a small plastic bite block attached to a handle. (Fig.1A) The size of bite block is $20 \mathrm{x} 10$ $\mathrm{mm}$ and is pyramidal in shape. At the apex of the pyramid, is a small concavity that accommodates the cusp of a tooth. Then, placed to the suspected tooth and patient is asked to bite. (Fig.1B) Pain on biting or on release of pressure is a sign that cracked tooth syndrome (CTS) present. It is speculated that this sharp pain is generated by an alternating streching and compressing of odontoblastic proccessus in the cracks. ${ }^{1,2,5}$

Magnifying glasses (including the endodonticoperating microscope), transilumination, staining with methylen blue are another useful tools to visualize the cracks. ${ }^{2,5}$

Nowadays, ultrasound imaging system is being used to detect the cracks. The use of radiographs is of little significance since many cracks run in a mesiodistal direction, thus are not visible on a radiograph., ${ }^{2,6}$ Other clue of CTS is an unfilled tooth or a shallow restoration.

\section{Treatment}

When teeth are unrestored and no part of the teeth breaks away or the existence of a crack can only be presumed, Ehrmann and Tyas advocate the application of a stainless steel orthodontic band. Tightly fit stainless steel band would seem to help in establishing the diagnosis. If the pain ceased, it confirms the diagnosis. The band serves as a splint and is cemented using carboxylate cement. Stainless steel band is recommended because it is contoured and less irritated to the gingival tissues. After cementation of the band, the test should be repeated using wood stick, usually the pain stops. The tooth can be used normally and patient is asked to return after 2-4 weeks. If the patient can chew normally, the band can be kept in place and a full coverage restoration can be planned either an onlay or a full gold crown. ${ }^{1}$

If sensitivity to temperature changes has not ceased, then endodontic therapy should be considered. The crack may extend close to the pulp or may involve the pulp. While endodontic 
therapy is performed, the band can stay in place, serve as a matrix until the tooth is ready for crown preparation. During fabrication of the crown, the tooth should be protected as the pain could recur under stress.

\section{DISCUSSION}

According to Ehrmann and Bates (cited from Ehrmann and Tyas), in majority of CTS cases, patient can point accurately the affected tooth, which is in contrast as reported by many authors. Teeth exhibiting CTS are markedly different from those with pulpitis or necrotic which are usually difficult to localize. This is due to the abundant of proprioceptive fibres in the periodontal ligament while the pulp doesn't have any. If the crack involves the pulp, the application of any force may cause disaster and application of fit stainless steel band would be more gentle to establish the diagnosis. Many of CTS cases reported were not visible. $^{1-6}$

A distinction could be made between CTS which is an incomplete fracture and a split tooth. If CTS is diagnosed and treated earlier, the prognosis is excellent.

If a split is marked and run from mesial to the distal surface, the prognosis is very poor. Such splits are just noted during endodontic therapy in the floor of the pulp chamber. ${ }^{6}$

Dewberry (cited from Ehrmann and Tyas) explained the cause of pain occurred in CTS as being due to 'streching and rupturing' of odontoblastic proccessus in the fracture line. ${ }^{1}$

The etiology of CTS is not fully understood especially when occurred in completely unrestored or minimally restored teeth. Hiatt (cited from Ehrmann and Tyas) suggested that an internal structure weakness might exist between cusps at calcification sites that failed to coalesce. The fact that 69 per cent of cases occur in lower molars is a proof. In addition, lower molars have a deeper central fossa than upper molars and the lingual cusps of upper molars may act as 'plungers' which induce structural fatigue in their mandibular antagonists.

Another possible cause is thermal cycling. Brown et al reported that cracks will develop in enamel from thermal tensile stresses due to transient heat conducted more readily in enamel than dentine.

At the DEJ where the planes of cleavage are weak, vertical enamel fractures are noted after 3000 thermal cycles between $32^{\circ} \mathrm{C}$ and $60^{\circ} \mathrm{C}$. This is possible to occur in the mouth in less than one year of eating and drinking.

Some patients have more than one tooth affected by CTS and about 21 per cent had more than one tooth with CTS as reported by Hiatt.

Cracked tooth syndrome can be found in our daily practice. It is marked by eratic pain on mastication especially with release of biting pressure. Location, direction and extension of the crack may affect the signs and symptoms of CTS. Some measures can be used to diagnose the CTS, such as asking the patient to bite a firm object; orange wood stick or plastic bite block; tooth sloth or other similar devices which is intended to induce such typical pain.

Cracked tooth syndrome can be successfully treated when early diagnosis could be made, the patients present early enough and the practitioners can recognize this condition. Application of stainless steel band will frequently cease the symptoms. The suggested ideal permanent restorations for such teeth is a full coverage crown and majority of teeth can be retained.

\section{REFERENCES}

1. Ehrmann EH, Tyas MJ. Cracked tooth syndrome: diagnosis, treatment and correlation 
between symptoms and post-extraction findings. Aust Dent J 1990; 35(2): 105-12.

2. Mittal N, Sharma V, Minocha A. Management of cracked teeth - a case report. Endodontology 2007; 19 (1). Available from: http://medind. nic.in/eaa/t07/i1/eaat07ip39.pdf.

3. Abbott PV. Assessing restored teeth with pulp and periapical diseases for the presence of cracks, caries and marginal breakdown. Aust Dent J 2004; 49(1): 33-9.
4. Turp JC, Gobetti JP. The cracked tooth syndrome, an elusive diagnosis. J Am Dent Assoc 1996; 127.

5. Cohen S, Liewehr F. Diagnostic procedures in pathways of the pulp. $8^{\text {th }}$ Ed. St. Louis: Mosby Inc.; 2002. p.24-6.

6. Ingle JI, Bakland LK. Endodontics. $5^{\text {th }}$ Ed. London: B C Decker Inc, Hamilton; 2002. p.254. 